\title{
EFISIENSI FITOREMEDIASI TANAMAN BAMBU AIR (Equisetum hyemale) DALAM MENURUNKAN KADAR BOD DAN COD AIR LIMBAH RUMAH TANGGA DI DESA KRACAK KECAMATAN AJIBARANG KABUPATEN BANYUMAS TAHUN 2016
}

\author{
Destara Margowati ${ }^{1)}$, Sugeng Abdullah ${ }^{2)}$ \\ Jurusan Kesehatan Lingkungan, Politeknik Kesehatan Kemenkes Semarang, \\ Jl. Raya Baturaden KM 12 Purwokerto, Indonesia
}

\begin{abstract}
ABSTRAK
Penelitian ini adalah untuk mengetahui efisiensi fitoremediasi tanaman bambu air (Equisetum hyemale) untuk menurunkan kadar BOD dan COD limbah rumah tangga di desa Kracak kecamatan Ajibarang kabupaten Banyumas Tahun 2016. Penelitian yang dilakukan merupakan penelitian Pre Eksperiment dengan pendekatan pretest dan post test design, yaitu memberikan perlakuan kemudian dilakukan pengukuran dengan maksud untuk mengetahui efisiensi tanaman bambu air. Hasil penelitian yang telah dilakukan di laboratorium menunjukan bahwa fitoremediasi air limbah rumah tangga dengan menggunakan tanaman bambu air dengan variasi berat $0,5 \mathrm{~kg}$ dapat menurunkan kadar BOD dan COD masing-masing sebesar $80,55 \%$ dan 76,35\% sedangkan berat tanaman 0,75 $\mathrm{kg}$ dapat menurunkan kadar BOD dan COD masing-masing sebesar 86,19\%dan 73,69\%. Berdasarkan hal tersebut maka fitoremediasi air limbah menggunakan tanaman bambu air dapat menurunkan kadar BOD dan COD baik pada berat tanaman $0,5 \mathrm{~kg}$ dan $0,75 \mathrm{~kg}$, walaupun untuk penurunan COD belum mencapai efisiensi removal sebesar 85\%. Sebaiknya perlu dilakukan penelitian lebih lanjut dengan variasi debit dan waktu tinggal.
\end{abstract}

Kata Kunci $\quad$ : $\quad$ Fitoremediasi, air limbah, BOD, COD

\section{PENDAHULUAN}

Seiring dengan pertumbuhan penduduk yang begitu cepat, akan membawa dampak meningkatnya kepadatan pemukiman dan perumahan. Dengan demikian limbah rumah tangga yang dihasilkan akan semakin besar kuantitasnya. Mengingat begitu besar pengaruh air limbah terhadap kesehatan manusia, maka perlu adanya pengolahan dan pengawasan terhadap air limbah tersebut (Agus Sutanto, 2011, h. 1).

Bambang Purwanto (Muhammad Nur' arif, 2008) menyebutkan bahwa volume limbah cair yang dihasilkan oleh setiap orang mulai dari mandi, cuci dan lain-lain mencapai 100 liter per hari. Menurut Rochana (Amaliyah Nurul Hidayah dan Yulinah Trihadiningrum, 2009) sumber pencemar badan air perkotaan $60 \%$ disumbang oleh air limbah domestik. Pembuangan air limbah domestik yang tidak mendapatkan perhatian serius dapat menurunkan kualitas air di badan air.

Sebagai langkah pengendalian terhadap pencemaran yang diakibatkan oleh air limbah khususnya air limbah rumah tangga, maka pemerintah mengeluarkan berbagai peraturan yang mengatur masalah kelayakan air diantaranya adalah : Peraturan Menteri Negara Lingkungan Hidup Nomor 05 tahun 2014 tentang Baku Mutu Air Limbah khususnya BOD yang terkandung adalah maksimal $100 \mathrm{mg} / \mathrm{l}$ dan untuk COD yang terkandung adalah maksimal $100 \mathrm{mg} / \mathrm{l}$.

Tanaman air sanggup menyerap kotoran yang ukurannya sangat lembut dan melayang dalam air dan

1) Email : destara.margowati@gmail.com

2) Email : sugengzend2016@gmail.com dipergunakan sebagai pupuk, sehingga kondisi air tampak lebih jernih dan bersih. Oleh karena itu tanaman air dapat berperan sebagai pengelola polutan/ limbah cair yang murah dan alami. Perluasan areal pemukiman akibat kepadatan penduduk yang tinggi menyebabkan peningkatan aktivitas manusia di rumah tangga. Hal ini berdampak pada semakin besarnya volume limbah dalam bentuk apapun yang dihasilkan dari waktu ke waktu yang tentunya menimbulkan dampak negativ terhadap kelestarian lingkungan. Teknologi pengolahan limbah cair rumah tangga di berbagai tempat di tanah air masih banyak belum terjangkau. Selain biaya yang mahal dan penerapannya yang sulit, masih kuatnya pemikiran dan anggapan sebagian besar masyarakat bahwa pembuangan limbah rumah tangga secara langsung ke lingkungan tidak akan menimbulkan dampak yang serius.

Salah satu upaya pemanfaatan sumber daya alam yang diketahui memiliki kaitan erat dengan proses pengolahan limbah rumah tangga adalah memanfaatkan jenis tanaman air yang banyak tumbuh pada saluran buangan limbah di sekitar pemukiman (Rony Irawanto, 2010).

Tanaman air merupakan bagian dari vegetasi penghuni bumi ini, yang media tumbuhnya adalah perairan. Penyebarannya meliputi perairan air tawar, payau sampai ke lautan dengan beranekaragam jenis, bentuk dan sifat. Jika memperhatikan sifat dan posisi hidupnya di perairan, tanaman air dapat dibedakan dalam 4 jenis, yaitu: tanaman air yang hidup pada bagian tepian perairan,disebut marginal aquatic plant; 
tanaman air yang hidup pada bagian permukaan perairan, disebut floating aquatic plant; tanaman air yang hidup melayang di dalam perairan, disebut submergeaquatic plant; dan tanaman air yang tumbuh pada dasar perairan, disebut the deep aquatic plant (Rony Irawanto, 2010).

Jenis-jenis tanaman yang sering digunakan di Fitoremediasi diantaranya adalah Anturium Merah atau kuning, Alamanda kuning atau ungu, Akar wangi, Bambu air, Cana presiden merah atau kuning atau putih, Dahlia, Dracenia merah atau hijau, Heleconia kuning atau merah, Jaka, Keladi loreng atau sente atau hitam, Kenyeri merah atau putih, Lotus kuning atau merah, Onje merah, Pacing merah atau putih, Padi-padian, Papirus, Pisang Mas, Ponaderia, Sempol merah atau putih, Spider lili, dll ( Rony Irawanto, 2010).

Warga desa kracak masih ada yang membuang air limbah rumah tangganya tidak di SPAL (Saluran Pembuangan Air Limbah) ada yang di pekarangan rumah, di selokan, di parit. Keterbatasan lahan dan biaya untuk pembuatan SPAL (Saluran Pembuangan Air Limbah) menjadi salah satu alasan warga masih membuang air limbah secara sembarangan.

Beberapa keunggulan tanaman bambu air antara lain; tanaman ini dapat mudah tumbuh dimana saja, mudah perawatannya, dan tahan terhadap berbagai pengaruh luar. (Moh. Mishbahul Anam MS, dkk. 2013).Tanaman bambu air mempunyai batang dengan kandungan silikat yang tinggi, yang berguna untuk mengikat partikel yang terserap oleh akar tanaman (Bambang Suharto dkk. 2011).

\section{BAHAN DAN METODE}

Penelitian ini dilaksanakan pada bulan Juni-Juli 2016 di UPTD Laboratorium Kesehatan Kabupaten Purbalingga. Bahan yang digunakan meliputi tanaman Bambu Air (Equisetum hyemale) kira-kira berumur 3-4 bulan. Limbah rumah tangga yang digunakan, diambil di desa Kracak kecamatan Ajibarang kabupaten Banyumas. Penelitian yang dilakukan merupakan penelitian pre eksperiment dengan pendekatan pretest dan post test design, yaitu memberikan perlakuan kemudian dilakukan pengukuran dengan maksud untuk mengetahui efisiensi tanaman bambu air.

\section{a. Cara kerja}

Perlakuan. Aklimasi tanaman selama 1 minggu pada kontainer yang berisi tanaman bambu air masing-masing seberat 0,5 kg dan 0,75 kg dengan umur kira-kira 3-4 bulan. Dalam proses pengolahan terdapat 3 kontainer utama yaitu kontainer kontrol, kontainer 1 dan kontainer 2. Antara kontainer kontrol, kontainer 1 dan kontainer 2 dibedakan dalam hal variasi berat tanaman, untuk kontainer kontrol mempunyai berat tanaman $0 \mathrm{~kg}$ atau tanpa tanaman, kontainer 1 mempunyai berat tanaman $0,5 \mathrm{~kg}$ dan kontainer 2 mempunyai berat tanaman $0,75 \mathrm{~kg}$. Kontainer 1 dan kontainer 2 terdapat replikasi sebanyak 2 kontainer sehingga pada kontainer yang diisi tanaman bambu air dengan berat 0,5 kg jumlah kontainer ada 3 begitupun dengan kontainer 2, namun untuk kontainer kontrol tidak ada replikasi. Media air pada kontainer aklimasi dibuang dan diganti dengan air limbah baru sebanyak \pm 29 L. Sebelum perlakuan air limbah rumah tangga di ukur parameter BOD, COD, $\mathrm{pH}$, dan suhu, kemudian biarkan air limbah selama 3 hari di kontainer perlakuan baik yang $0 \mathrm{~kg}$ (tanpa tanaman), 0,5 kg dan 0,75 kg, setelah 3 hari ukur kembali parameter BOD, COD pH, dan suhu.

Data parameter kualitas air limbah rumah tangga meliputi BOD, COD, pH, dan suhu.

\section{III.HASIL DAN PEMBAHASAN}

\section{a. Kualitas air limbah sebelum dilakukan} pengolahan

Parameter uji penurunan air limbah rumah tangga di Desa Kracak, Kecamatan Ajibarang, Kabupaten Banyumas meliputi BOD, COD, pH, dan suhu yang menggunakan tanaman bambu air (Equisetum hyemale) dengan sistem wetland. Jumlah tanaman yang digunakan adalah seberat 0,5 kg, 0,75 kg, dan $0 \mathrm{~kg}$ (sebagai kontainer kontrol).

Berdasarkan hasil pengukuran BOD, COD, $\mathrm{pH}$, dan suhu limbah awal pada tabel 1, maka air limbah harus dilakukan pengolahan terlebih dahulu sebelum dibuang langsung ke perairan karena nilai BOD dan COD masih melebihi ambang batas baku mutu air limbah. Ada beberapa macam perlakuan yang dapat dilakukan, salah satunya dengan menggunakan sistem lahan basah. Sistem Lahan Basah dapat diklasifikasikan menjadi CWs dengan permukaan air bebas (Free Water Surface/FWS) dan CWs aliran di bawah permukaan (Sub Surface Flow/SSF). Berdasarkan pola aliran, CWs dapat diklasifikasikan menurut arah aliran horisontal dan vertikal menurut Vymazal (Anna Catharina Sri Purna Suswati dan Gunawan Wibisono, 2013). Pada penelitian ini perlakuan air limbah dilakukan dengan sistem wetland menggunakan tanaman bambu air (Equisetum hyemale).

Sistem pengolah limbah Wetlands ini hanya membutuhkan bak-bak (kolam) sederhana, sehingga tidak membutuhkan biaya besar untuk membuat instalasi bangunannya. Pengolahan limbah mengandalkan kinerja tanaman dan mikrobia yang bekerja secara alamiah, sehingga tidak membutuhkan sistem pengoperasian yang rumit dan dapat menekan biaya operasionalnya. Pengolahan limbah domestik dengan sistem lahan basah buatan (Wetlands) sangat mengandalkan kemampuan bakteri dan tanaman air dalam mengolah limbah. (Mika Septiawan Muhajir, 2013). Berdasarkan tabel 1 yang didapat dari pemeriksaan di laboratorium, hasil dari pemeriksaan awal kualitas air limbah kadar BOD 
dan COD masih melebihi baku mutu air limbah yaitu untuk parameter BOD $1705 \mathrm{mg} / \mathrm{l}$ dan COD $313 \mathrm{mg} / \mathrm{l}$ sedangkan baku mutu air limbah menurut Peraturan Daerah Prop. Jateng No. 05 Tahun 2012 tentang Baku Mutu Air Limbah untuk BOD $100 \mathrm{mg} / \mathrm{l}$ dan COD $250 \mathrm{mg} / \mathrm{l}$.

Parameter lainnya seperti $\mathrm{pH}$ dan suhu masing-masing sebesar 4,5 dan $26^{\circ} \mathrm{C}$. Bakteri akan tumbuh baik pada temperatur optimum 25$40^{\circ} \mathrm{C}$ dan pada umumnya bakteri tak dapat bertahan pada $\mathrm{pH}>9,5$ atau $<4,0$, $\mathrm{pH}$ optimum umumnya berkisar antara 6-7,5. (Herlina,2007).

Untuk kondisi temperatur udara sekitar tempat pengolahan adalah $28^{\circ} \mathrm{C}$. Temperatur air limbah akan seimbang dengan temperatur udara luar dengan selisih $\pm 3^{\circ} \mathrm{C}$.Dalam penelitian ini didapatkan selisih temperatur $1-2{ }^{\circ} \mathrm{C}$ berarti temperatur pengolahan seimbang dengan temperatur udara luar.

Tabel 1 Kualitas air limbah sebelum pengolahan dengan wetland di Desa Kracak Kecamatan Ajibarang Kabupaten Banyumas Tahun 2016

\begin{tabular}{clccl}
\hline No & Parameter & Satuan & Kadar & $\begin{array}{c}\text { Baku } \\
\text { Mutu* }\end{array}$ \\
\hline 1. & BOD & $\mathrm{Mg} / \mathrm{L}$ & 1075 & 100 \\
\hline 2. & COD & $\mathrm{Mg} / \mathrm{L}$ & 313 & 250 \\
\hline 3. & $\mathrm{pH}$ & - & 4,5 & $6-7$ \\
\hline 4. & Suhu & oC & 26 & - \\
\hline
\end{tabular}

Sumber : Hasil Pemeriksaan di UPTD Laboratorium Kesehatan Kabupaten Purbalingga

(*) Baku mutu limbah cair menurut Peraturan Daerah Provinsi Jawa Tengah No.5 Tahun 2012

b. Kualitas air limbah setelah dilakukan pengolahan

Pengolahan air limbah dilakukan dengan sistem wetland menggunakan tanaman bambu air (Equisetum hyemale) yang dilakukan selama 3 hari dengan variasi berat tanaman $0 \mathrm{~kg} /$ tanpa tanaman (sebagai kontrol), 0,5 kg dan 0,75 kg pada masing-masing kontainer.

Berdasarkan tabel 2 setelah dilakukan pengolahan dengan sistem wetland selama 3 hari didapatkan hasil penurunan parameter air limbah, yaitu:

\section{Hasil pengukuran BOD dan COD}

Hasil pemeriksaan BOD pada kontainer kontrol sebesar $786 \mathrm{mg} / \mathrm{l}$, untuk kontainer dengan berat tanaman 0,5 kg sebesar $209 \mathrm{mg} / \mathrm{l}$ dan kontainer dengan berat tanaman 0,75 kg sebesar $149 \mathrm{mg} / \mathrm{l}$ dari hasil awal sebelum pengolahan sebesar $1075 \mathrm{mg} / \mathrm{l}$. Jika melihat kadar maksimum parameter BOD yang ditetapkan oleh Peraturan Daerah Provinsi Jawa Tengah No 05 Tahun 2012, kadar maksimum BOD pada air limbah adalah sebesar $100 \mathrm{mg} / \mathrm{l}$, sehingga dapat dikatakan bahwa air limbah tersebut belum memenuhi syarat baku mutu walaupun telah mengalami penurunan.

Berdasarkan hasil pemeriksaan COD pada kontainer kontrol sebesar $74 \mathrm{mg} / \mathrm{l}$, untuk kontainer dengan berat tanaman 0,5 kg 74,67 sebesar $\mathrm{mg} / \mathrm{l}$ dan kontainer dengan berat tanaman 0,75 kg sebesar 82,34 mg/l dari kadar sebelum pengolahan adalah $313 \mathrm{mg} / \mathrm{l}$. Hasil pemeriksaan COD tersebut didapatkan hasil yang pada setiap kotainer telah memenuhi syarat baku mutu yang telah ditetapkan yaitu sebesar $250 \mathrm{mg} / \mathrm{l}$. Syarat tersebut berdasarkan Peraturan Daerah Provinsi Jawa Tengah No 05 Tahun 2012 tentang baku mutu air limbah.

Tabel 2 Hasil Rata-rata Kualitas air limbah setelah pengolahan dengan wetland di Desa Kracak Kecamatan Ajibarang Kabupaten Banyumas Tahun 2016

\begin{tabular}{|c|c|c|c|}
\hline \multirow{3}{*}{\multicolumn{2}{|c|}{ No ParameterSatuan }} & \multicolumn{2}{|c|}{ Unit Pengolahan } \\
\hline & \multicolumn{3}{|c|}{ Kontainer KontainerKontainer } \\
\hline & Kontrol & \multirow{2}{*}{1} & \multirow{2}{*}{$\frac{2}{149}$} \\
\hline 1. BOD & $\mathrm{Mg} / \mathrm{L} 786$ & & \\
\hline 2. $\mathrm{COD}$ & $\mathrm{Mg} / \mathrm{l} \quad 74$ & 74,67 & 82,34 \\
\hline 3. $\mathrm{\jmath} \mathrm{H}$ & $-\quad \overline{3,5}$ & 5,5 & 5,5 \\
\hline 4. Suhu & oC $\quad 28$ & 26 & 26 \\
\hline Suml & $\begin{array}{l}\text { Hasil Pemeriks } \\
\text { Laboratorium Ke } \\
\text { Purbalingga }\end{array}$ & $\begin{array}{l}\text { an } d \\
\text { ehatan }\end{array}$ & $\begin{array}{r}\text { UPTD } \\
\text { Kabupaten }\end{array}$ \\
\hline
\end{tabular}
sesudah pengolahan dengan wetland di Desa Kracak Kecamatan Ajibarang Kabupaten Banyumas Tahun 2016

\begin{tabular}{|c|c|c|c|c|c|}
\hline \multirow[b]{2}{*}{ Parameter } & \multirow[b]{2}{*}{ Satuan } & \multirow[b]{2}{*}{ Sebelum } & \multicolumn{3}{|c|}{ Sesudah } \\
\hline & & & KK & K1 & K2 \\
\hline 1. BOD & $\mathrm{Mg} / \mathrm{l}$ & 1075 & 786 & 209 & 149 \\
\hline 2. $\mathrm{COD}$ & $\mathrm{Mg} / \mathrm{l}$ & 313 & 74 & 74,67 & 82,34 \\
\hline 3. $\mathrm{pH}$ & - & 4,5 & 5,5 & 5,5 & 5,5 \\
\hline 4. Suhu & ${ }^{\circ} \mathrm{C}$ & 26 & 28 & 26 & 26 \\
\hline $\begin{array}{r}\text { Sumber : Has } \\
\text { Lab } \\
\text { Purl }\end{array}$ & $\begin{array}{l}\text { il } P e \\
\text { oratoriuı } \\
\text { balingga }\end{array}$ & $\begin{array}{l}\text { meriksaan } \\
\text { n Keseha }\end{array}$ & $\tan$ & $\begin{array}{r}\text { UI } \\
\text { Kabup }\end{array}$ & \\
\hline
\end{tabular}

\section{Hasil Pengukuran pH}

Rahayu (Moh. Mishbahul Anam MS, Evi Kurniati, Bambang Suharto, 2013) Salah satu pengukuran yang sangat penting dalam berbagai cairan proses (industri, farmasi, manufaktur, produksi makanan dan sebagainya) adalah $\mathrm{pH}$, yaitu pengukuran ion hidrogen dalam suatu larutan. Larutan dengan harga pH rendah dinamakan "asam" sedangkan yang harga pH-nya tinggi dinamakan "basa”. Skala pH terentang dari 0 (asam kuat) sampai 14 (basa kuat) dengan 7 (netral) adalah harga tengah mewakili air murni. 
Pengukuran $\mathrm{pH}$ dilakukan setiap hari pada masing - masing bak perlakuan. Pemeriksaan nilai $\mathrm{pH}$ pada masing-masing bak pengolahan didapatkan rata-rata 5,5. Hasil ini masih dibawah baku mutu untuk $\mathrm{pH}$ yang sebesar 69, namun dibanding dengan $\mathrm{pH}$ awal sebelum pengolahan dapat dilihat mengalami kenaikan. Menurut Arie Herlambang (BPPT 2002, h.166), kebanyakan pertumbuhan bakteri metanogenik berada pada kisaran $\mathrm{pH}$ antara 6,7-7,4, tetapi optimalnya pada kisaran $\mathrm{pH}$ antara 7,0 - 7,2 dan proses dapat gagal jika $\mathrm{pH}$ mendekati 6,0. Bakteri asidogenik menghasilkan asam organik, yang cenderung menurunkan $\mathrm{pH}$ bioreaktor. Pada kondisi normal, penurunan $\mathrm{pH}$ ditahan oleh ion bikarbonat yang dihasilkan oleh bakteri metanogen

3. Hasil pengukuran suhu air limbah dan suhu lingkungan

Selain air limbah diukur $\mathrm{pH}$ nya juga dilakukan pengukuran suhu air limbah yang diujikan. Pengukuran ini bertujuan untuk mengetahui besarnya suhu pada tiap perlakuan. Pengukuran suhu pada air limbah dilakukan pada waktu yang hampir bersamaan dengan pengukuran suhu lingkungan. Hal ini dimaksudkan untuk menyesuaikan perubahan suhu pada air limbah dengan suhu lingkungan. Pengukuran suhu dilakukan pada pukul 10.30 wib. Waktu ini dipilih berdasarkan waktu tanam perlakuan.

Hasil pengukuran suhu air limbah di masingmasing bak didapatkan hasil, pada kontainer kontrol (berat tanaman $0 \mathrm{~kg} /$ tanpa tanaman) sebesar 28oC, pada kontainer 1 (berat tanaman $0,5 \mathrm{~kg}$ ) sebesar 26 oC dan pada kontainer 2 (berat tanaman 0,75 kg) sebesar 26 oC. Temperatur limbah cair sesudah pengolahan didapatkan hasil $28^{\circ} \mathrm{C}-26^{\circ} \mathrm{C}$. Menurut Bowo Djoko Marsono (Herlina, 2007) bakteri akan tumbuh baik pada suhuoptimum $25-40^{\circ} \mathrm{C}$.

Untuk kondisi temperatur udara sekitar tempat pengolahan adalah rata-rata $28{ }^{\circ} \mathrm{C}$. Menurut Asdak (Herlina, 2007), temperatur air limbah akan seimbang dengan temperatur udara luar dengan selisih $\pm 3^{\circ} \mathrm{C}$. Dalam penelitian ini didapatkan selisih temperatur $1-2{ }^{\circ} \mathrm{C}$ berarti temperatur pengolahan seimbang dengan temperatur udara luar.

\section{c. Efisiensi pengolahan air limbah}

Berdasarkan tabel 4 untuk penurunan kadar BOD pada masing-masing kontainer, berdasarkan nilai sebelum dan sesudah pengolahan adalah untuk kontainer kontrol (berat tanaman $0 \mathrm{~kg} /$ tanpa tanaman) sebesar 26,88\%, kontaner 1 (berat tanaman 0,5 kg) sebesar 80,55\% dan untuk kontainer 2 (berat tanaman 0,75 kg) sebesar 86,19\%. Dilihat dari hasil tersebut penurunan yang paling besar pada kontainer 2 dengan berat tanaman $0,75 \mathrm{~kg}$ yaitu sebesar 86,19\%.

Kemampuan bambu air sebagai fitoremediator dikarenakan adanya mikroba rhizosfera pada akar yang dapat mengurai zat-zat kontaminan dengan cara menyerapnya dari perairan dan kemudian mengakumulasi bahan terlarut ke dalam struktur tubuhnya, sehingga semakin banyak tanaman bambu air maka semakin besar penurunan kadar BOD nya.

Penurunan kadar COD berdasarkan nilai sebelum dan sesudah menunjukan hasil untuk kontainer kontrol (berat tanaman $0 \mathrm{~kg} / \mathrm{tanpa}$ tanaman) sebesar 76,35\%, kontainer 1 (berat tanaman $0,5 \mathrm{~kg}$ ) sebesar $76,14 \%$ dan untuk kontainer 2 (berat tanaman $0,75 \mathrm{~kg}$ ) sebesar 73,69\%. penurunan terendah untuk kadar COD pada tanaman bambu air (Equisetum hyemale) seberat $0,75 \mathrm{~kg}$ dengan nilai COD $82,34 \mathrm{mg} / \mathrm{L}$ (73,69\%), dan penurunan maksimum terjadi pada tanaman $0 \mathrm{~kg}$ (tanpa tanaman) dengan nilai COD $74 \mathrm{mg} / \mathrm{L}(76,35 \%)$.

Berdasarkan hasil penurunan kadar COD pada saat perlakuan dengan tanaman bambu air (Equisetun hyemale) dengan berat tanaman 0,75 kg mengalami penurunan yang lebih sedikit dibandingkan dengan perlakuan menggunakan berat tanaman 0,5 kg dan tanpa tanaman / $0 \mathrm{~kg}$ hal ini berkaitan dengan fungsi perakaran tanaman bambu air dalam menyerap dan mengurai polutan dan penurunan kandungan COD yang belum maksimal serta kemampuan tanaman yang hanya dapat menurunkan air limbah degradable sehingga penurunan kadar COD dengan berat tanaman 0,75 kg lebih sedikit.

Tabel 4 Efisiensi pengolahan air limbah dengan wetland di Desa Kracak Kecamatan Ajibarang Kabupaten Banyumas Tahun 2016

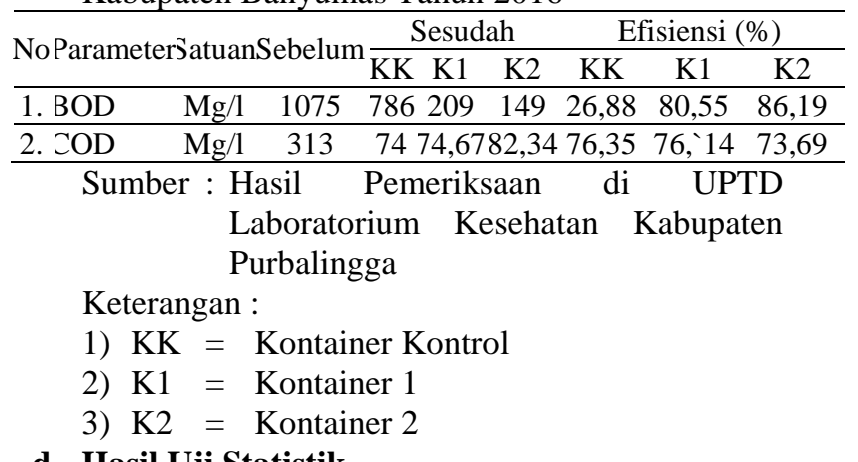

\section{d. Hasil Uji Statistik}

Uji paired t test yang dilakukan menggunakan software Komputer dapat dilihat pada tabel 5 dan 6

Tabel 5 Hasil Uji Statistik $t$ Test (Pre-Post) BOD Pengolahan air limbah dengan sistem wetland di Desa Kracak Kecamatan Ajibarang Kabupaten Banyumas Tahun 2016

\begin{tabular}{ccccc}
\hline Nilai $\boldsymbol{\alpha}$ & Df & P & \multicolumn{1}{c}{ Nilai $\boldsymbol{\alpha}$} & \multicolumn{1}{c}{ Hasil } \\
\hline $5 \%$ & 2 & 0,000 & 0,050 & $\mathrm{P}<\alpha$ \\
& & & & $0,000<0,050$ \\
\hline
\end{tabular}


Tabel 6 Hasil Uji Statistik $t$ Test (Pre-Post) COD Pengolahan air limbah dengan sistem wetland di Desa Kracak Kecamatan Ajibarang Kabupaten Banyumas Tahun 2016

\begin{tabular}{llccc}
\hline Nilai $\boldsymbol{\alpha}$ & Df & P & Nilai $\boldsymbol{\alpha}$ & Hasil \\
\hline $5 \%$ & 3 & 0,760 & 0,050 & $\mathrm{P}>\alpha$ \\
& & & & $0,760<0,050$ \\
\hline
\end{tabular}

Tabel 7 Hasil Uji Statistik independent Test pada kontainer perlakuan $0,5 \mathrm{~kg}$ dan $0,75 \mathrm{~kg}$ Pengolahan air limbah dengan sistem wetland di Desa Kracak Kecamatan Ajibarang Kabupaten Banyumas Tahun

\begin{tabular}{lcccc}
\hline Nilai $\boldsymbol{\alpha}$ & Df & P & Nilai $\boldsymbol{\alpha}$ & \multicolumn{1}{c}{ Hasil } \\
\hline $5 \%$ & 2 & 0,076 & 0,050 & $\mathrm{P}>\alpha$ \\
& & & & $0,076>0,050$ \\
\hline
\end{tabular}

Uji statistik menggunakan uji t-test, uji beda dua mean data berpasangan dengan nilai $\alpha=5 \%$, $\mathrm{Df}=2$, dan nilai $\mathrm{p}=0,076$ untuk BOD dan $\mathrm{p}=$ 0,000 untuk nilai COD berarti untuk uji statistik BOD tidak ada perbedaan penggunaan Bambu air (Equisetum hyemale) sebelum dan sesudah perlakuan karena nilai $\mathrm{p}>\alpha$ dan untuk parameter COD ada perbedaan penggunaan Bambu air (Equisetum hyemale) terhadap peningkatan kualitas air limbah rumah tangga karena nilai $\mathrm{p}<$ nilai $\alpha$.

Uji statistic menggunakan uji independent $t$ test untuk uji perbedaan pada kontainer perlakuan 1 (0,5 kg) dan kontainer perlakuan 2 (0,75 kg) didapatkan uji statistik nilai $\alpha=5 \%$, Df $=3$, dan nilai $\mathrm{p}=0,760$ berarti uji statistiknya tidak ada perbedaan antara kontainer perlakuan $1(0,5 \mathrm{~kg})$ dan kontainer perlakuan $(0,75 \mathrm{~kg})$.

\section{IV.KESIMPULAN}

a. Kualitas air limbah sebelum pengolahan dengan metode wetland di Desa Kracak didapatkan hasil untuk parameter BOD sebesar $1075 \mathrm{mg} / \mathrm{l}$, COD sebesar $313 \mathrm{mg} / \mathrm{l}$, pH sebesar 4,5 dan Suhu sebesar $28^{\circ} \mathrm{C}$

b. Kualitas air limbah setelah pengolahan dengan wetland di Desa Kracak di dapatkan hasil untuk Kontainer 1 ( kontainer perlakuan dengan berat tanaman $0,5 \mathrm{~kg}$ ) untuk pengukuran parameter air limbah untuk BOD sebesar 209 mg/l, COD sebesar 74,67, pH sebesar 5,5 dan Suhu sebesar $26{ }^{\circ} \mathrm{C}$ serta untuk kontainer 2 ( kontainer perlakuan dengan berat tanaman 0,75 $\mathrm{kg}$ ) didapatkan hasil pengukuran parameter air limbah untuk BOD sebesar $149 \mathrm{mg} / \mathrm{l}$, COD sebesar 82,34 mg/l , pH sebesar 5,5 dan Suhu sebesar $26^{\circ} \mathrm{C}$

c. Perbedaan Kualitas air limbah sebelum dan sesudah pengolahan dengan wetland di Desa Kracak Kecamatan Ajibarang Kabupaten Banyumas Tahun 2016 di lihat dari uji statistic bahwa untuk parameter BOD tidak ada perbedaan bermakna kualitas air limbah sebelum dan sesudah pengolahan dengan wetland dan untuk parameter COD ada perbedaan bermakna kualitas air limbah sebelum dan sesudah pengolahan.

d. Efisiensi pengolahan air limbah dengan wetland di Desa Kracak Kecamatan Ajibarang Kabupaten Banyumas Tahun 2016 untuk parameter BOD dan COD di kontainer kontrol sebesar 26,88\% dan 76,35\%, sedangkan di kontainer 1 untuk BOD sebesar $80,55 \%$ dan COD sebesar 76,14\% dan di kontainer 2 untuk BOD sebesar 86,19\% serta untuk COD sebesar 73,69\%.

\section{DAFTAR PUSTAKA}

Agus Sutanto, 2011, "Studi Efektivitas beberapa tanaman air untuk menurunkan BOD limbah cair domestic di perumahan permata hijau kabupaten banyumas tahun 2011”, Purwokerto: Poltekkes Kemenkes Semarang Jurusan Kesehatan Lingkungan

Andhyka Septiana Nugraha, 2015,’Efisiensi Bambu Air (Equisetum hyemale) sebagai fitoremediasi kadar Biological Oxygen Demand pada limbah cair industri tahu di desa prembun kecamatan tambak kabupaten banyumas tahun 2015”, Purwokerto: Poltekkes Kemenkes Semarang Jurusan Kesehatan Lingkungan

Anna Catharina Sri Purna Suswati dan Gunawan Wibisono, 2013, "Pengolahan Limbah Domestik Dengan Teknologi Taman Tanaman Air (Constructed Wetlands)”, Malang: Program Studi Kajian Lingkungan, Program Pascasarjana, Universitas Brawijaya, Jurusan Teknik Sipil, Fakultas Teknik, Universitas Katholik Widya Karya, Malang, Indonesia dan Jurusan Teknik Sipil, Fakultas Teknik, Universitas Merdeka, Malang, Indonesia

Anonim, 2016, “ Bambu-air-equisetum-hyemale”, www.bunga-taman.com, Diakses tanggal 16 Januari 2016, Pukul 11.30 WIB

Anonim, 2016, “ Tanaman Bambu Air”, www.obunga.com, Diakses tanggal 20 Januari 2016, Pukul 13.15 WIB

Bambang Suharto, Liliya Dewi Susanawati, Betha Ika Wilistien, 2011, "Penurunan Kandungan Logam $\mathrm{Pb}$ dan $\mathrm{Cr}$ Leachate Melalui Fitoremediasi Bambu Air (Equisetum hyemale) dan Zeolit”,Malang: Fakultas Keteknikan Pertanian Universitas Brawijaya dan Fakultas Pertanian Universitas Trunojaya Bangkalan Madura

Djajeng Poedjowibowo, 2011, "Infrastruktur Limbah Terpadu Dalam Taman Lingkungan Permukiman Volume 3”, Manado: pJurusan 
Arsitektur, Fakultas Teknik Universitas Sam Ratulangi

Farid, Mudassar, Muhammad Irshad, Muhammad Fawad, Z. Ali Awan, A. Egrinya Eneji, and Naureen Aurangzeb, 2014,"Effect of Cyclic Phytoremediation with Different Wetland Plants on Municipal wastewater”, Department of Environmental Sciences, University of Haripur, Haripur, Pakistan Department of Environmental Sciences, COMSATS Institute of Information Technology, Abbottabad, Pakistan National Agricultural Research Station, Islamabad, Pakistan Department of Soil Science, University of Calabar, Nigeria.

Herlina Puji Prasetya, 2007, “ Efisiensi Model Pengolahan Anaerobik Digester Dalam Menurunkan BOD Limbah Cair Tahu Di Desa Kalisari Kecamatan Cilongok Kabupaten Bantumas Tahun 2007”, Purwokerto: Poltekkes Kemenkes Semarang Jurusan Kesehatan Lingkungan

K. Anning, Alexander, Percy E. Korsah, dan Patrick Addo-Fordjour, 2013, "Phytoremediation of Wastewater with Limnocharis lava, Thalia geniculata and Typha latifolia in Constructed Wetlands”, Kumasi: Department of Theoretical and Applied Biology, Kwame Nkrumah University of Science and Technology, Kumasi, Ghana.

Mika Septiawan Muhajir, 2013, “ Penurunan Limbah Cair BOD dan COD Pada Industri Tahu Menggunakan Tanaman Cattail (Typha angustifolia) Dengan Sistem Constructed Wetlad”, Semarang : Universitas Negeri Semarang Jurusan Kimia

Muhammad Nur' arif , 2008, “Pengolahan Air Limbah Domestik”, Semarang: Program Pascasarjana Magister Ilmu Lingkungan Universitas Diponegoro Semarang.
Muhammad Mishbalul Anam MS , Evi Kurniati, Bambang Suharto, 2013, "Penurunan Kandungan Logam $\mathrm{Pb}$ dan $\mathrm{Cr}$ Leachate Melalui Fitoremediasi Bambu Air ( Equisetum hyemale ) dan Zeolit”, Malang: Jurusan Keteknikan Pertanian Universitas Brawijaya.

Peraturan Daerah Provinsi Jawa Tengan Nomor 5 Tahun 2012 Tentang Baku Mutu Air Limbah

Peraturan Menteri Lingkungan Hidup Republik Indonesia Nomor 5 Tahun 2014 Tentang Baku Mutu Air Limbah

Rony Irawanto, 2010, "Fitoremediasi Lingkungan Dalam Taman Bali”, Malang:UPT Balai Konservasi Tumbuhan Kebun Raya Purwodadi-LIPI.

Soeparman dan Suparmin, 2002, Pembuangan Tinja \& Limbah Cair Cetakan 1, Jakarta:Buku Kedokteran EGC

Sugiharto, 2008, Dasar-dasar Pengolahan Air Limbah, Jakarta:Universitas Indonesia

Tri Cahyono, 2014, Pedoman Penulisan Proposal Penelitian dan Karya Tulis Ilmiah / Skripsi ( Edisi Revisi Ketiga ), Purwokerto: Politeknik Kesehatan Kemenkes Semarang Jurusan Kesehatan Lingkungan.

Vivi Kusumawati, 2015 “ Studi Instalasi Pengolahan Air Limbah Tahu di Desa Kalisari Kecamatan Cilongok Kabupaten Banyumas Tahun 2015”, Purwokerto: Poltekkes Kemenkes Semarang Jurusan Kesehatan Lingkungan

Wahyu Lestari, 2013, "Penggunaan Ipomoea aquatic Forsk. Untuk Fitoremediasi Limbah Rumah Tangga Tahun 2013”, Riau: Jurusan Biologi FMIPA Universitas Riau.

Wisnu Arya Wardhana, 1995, Dampak Pencemaran Lingkungan, Yogyakarta: Andi Offset 